\title{
THE VARIABILITY AND INTERDEPENDENCE OF BASIC TECHNOLOGICAL QUALITY PARAMETERS OF MAIZE HYBRIDS IN LONG-TERM RESEARCH
}

\author{
Valentina Nikolić1, Vojka Babić ${ }^{1}$, Natalija Kravić ${ }^{1}$, Milomir Filipović ${ }^{1}$, \\ Slađana Žilić ${ }^{1}$, Marijana Simić ${ }^{1}$, Milica Radosavljević ${ }^{1}$
}

\begin{abstract}
In the process of hybrid maize breeding, the greatest attention is directed towards increasing the level and stability of the yield, while grain quality is of secondary importance. The very principles of hybrid breeding, as well as the economic aspects and competition between different breeding companies, have led to an enormous narrowing of the genetic basis of commercial maize hybrids. Concurrently, there is usually a small number of often related hybrids of similar technological and nutritional quality present on the market. Six best-selling ZP maize hybrids in the previous ten years were chosen as the subject of this study. In the period from 2009-2018, both the yield components and parameters of technological and nutritional quality of the grain were studied. It was found that the examined parameters varied a lot in different years of production and that some parameters were more influenced by genotype (number of kernel rows per ear, portion of pericarp, and crude fiber content) while others were more influenced by the environment (kernel weight per ear, total protein, starch, and oil content, respectively). The amount and the distribution of precipitation during the vegetative period affected not only the yield components i.e. grain yield but also the technological qualitz parametres and nutritional properties of the grain. Based on the observed parental components, it is evident that they are related hybrids that, despite the high genotype by environment interactions, consequently have similar parameters of technological quality and nutritional composition. The imperative is to develop special breeding programs aiming to create both the starting material and parental components to provide hybrids of improved technological quality and nutritional properties on the market. In that way, the needs of the processing industry for raw materials of certain characteristics can be met.
\end{abstract}

Key words: commercial maize hybrids, yield components, grain physical properties, basic kernel chemical composition, PCA analysis.

\section{Introduction}

In previous decades, maize (Zea mays L.) has been both, one of the most important food, feed, energy and industrial crops worldwide, as well as, one of the primary genetic model organisms (Andorf et al., 2019). In 2021, the total world maize production estimated by the Unit- ed States Department of Agriculture (USDA) was 1.13 billion metric tons, with Serbia producing around 8 million metric tons and taking $16^{\text {th }}$ place (World Agricultural Production. com, 2021). Maize is the most important field crop in Serbia, cultivated on about one million hectares, annually. Its yield and stability have

Original scientific paper (Originalni naučni rad)

${ }^{1}$ Nikolić V, Babić V, Kravić N, Filipović M, Žilić S, Simić M, Radosavljević M, Maize Research Institute

Zemun Polje, S. Bajića 1, 11185 Belgrade, Serbia

*e-mail: valentinas@mrizp.rs 
a significant impact on the agriculture in general, as well as, on the gross domestic product (GDP) (Babić et al., 2016).

Quantifying and understanding genetic variations in maize hybrids is of utmost importance because it can boost breeding efforts for yield improvement, required to feed a growing world population (Bomert et al., 2013). The development of maize breeding was highly influenced by hybrid performance and heterosis. Thus, the questions of long-term research are linked to the biological basis of heterosis and to development of methods for predicting the hybrid performance of various combinations of inbred lines (Andorf et al., 2019). Even though there is a very wide genetic variability available to maize breeders, there is, at the same time, only a small number of hybrids present on the market. These hybrids are usually of similar genetic backgrounds and thus of similar technological quality. At the Maize Research Institute Zemun Polje, it was estimated that approximately 3000 inbreds in the hybrid combinations are tested each year. Out of the total number of hybrid combinations, thirty to forty of them (i.e. 50-60 inbreds) are tested by the Variety Release Committee and on average, 1020 hybrids, are released annually. On the other hand, only 1-2 out of this number of hybrids enter the commercial production (Babić et al., 2012).

Although certain efforts to create hybrids of improved technological and nutritive grain quality have been made in recent years (Vančetović et al., 2012; Žilić et al., 2012), grain yield remains a parameter of the greatest interest (Babić et al., 2011). Having in mind that it is practically impossible to monitor numerous grain quality parameters during the breeding process itself, it is of great importance that these parameters are determined after registration, and before the eventual commercialization of hybrids. After registration, hybrids enter pre-commercial research, which, in addition to the yield testing in multi-location macro trials, also includes assessment of the grain quality parameters. The Laboratory for Food Technology and Biochemistry of the Maize Research Institute examines the quali- ty parameters of between 30 and 40 different maize hybrids each year (Radosavljević et al., 2000). Moreover, perceiving differences regarding grain technological quality for a specific purpose from the local food industries is essential for the development of new and functional maize-based food products (Milašinović-Šeremešić et al., 2021).

One of the most environmentally sensitive phenophase in maize is the period of grain filling (El Sabagh et al., 2017). The environmental fluctuation affects the qualitative and quantitative parameters of grain productivity and may cause different influences on the development and maturing of the maize kernels and modify the grain-filling process, as well as, the deposition of reserves (Lu et al., 2014). Heat-induced stress largely affects the growth and development of field crops by leading to reduced grain weight with low starch, crude oil, and total protein contents (Barutcular et al., 2017).

Accordingly, the aim of this study was: i) to determine the dependence between the examined quality parameters ii) to establish the pattern of changes in quality parameters upon environmental fluctuation in different years of production, and iii) to determine whether there is a regularity in values and variation of the tested parameters that depend upon parental components using the principal components analysis (PCA).

\section{Material and methods}

\section{Plant material}

Six commercial maize hybrids registered on the National list in the period from 1990 to 2010 , were selected for this study (Table 1 ). In the last ten years, these were the best-selling hybrids on the market of the Republic of Serbia, and they were developed at the Maize Research Institute Zemun Polje. The list of the hybrids as well as the information on their parental components, is given in Table 1. 
Table 1. The evaluated plant material

Tabela 1. Ispitivani biljni materijal

\begin{tabular}{cccccc}
\hline No & $\begin{array}{c}\text { Commercial } \\
\text { hybrid name }\end{array}$ & Mother code & Heterotic group & Father code & Heterotic group \\
\hline 1 & ZP 341 & ZPL F1 & Iowa-dent & ZPL M1 & Lancaster \\
2 & ZP 434 & ZPL F1 & Iowa-dent & ZPL M2 & Lancaster \\
3 & ZP 555 & ZPL F2 & BSSS & ZPL M1 & Lancaster \\
4 & ZP 560 & ZPL F3 & BSSS & ZPL M2 & Lancaster \\
5 & ZP 606 & ZPL F2 & BSSS & ZPL M3 & Lancaster \\
6 & ZP 666 & ZPL F2 & BSSS & ZPL M2 & Lancaster \\
\hline
\end{tabular}

\section{Field experiments}

The two-replicate trial was set up according to the randomized complete-block design in the experimental field of the Maize Research Institute. All hybrids were sown in plots of $5 \mathrm{~m}$ long rows, with intra and inter-row spacing of $0.20 \mathrm{~m}$ and $0.75 \mathrm{~m}$, respectively (i.e. plant density was 66.700 plants $\mathrm{ha}^{-1}$ ), in four rows, using standard cropping practices at the location of Zemun Polje, Serbia $\left(44^{\circ} 52^{\prime} \mathrm{N}, 20^{\circ} 19^{\prime} \mathrm{E}, 81 \mathrm{~m}\right.$ asl). Maize ears of each replicate were harvested in the full physiological maturity stage from two inner rows.
The experiment was sown under rain fed conditions, in the period from 2009-2018 (marked in the analysis from 1-10, respectively). In the observed period, based on the amount and the distribution of precipitation, as well as, on average temperatures during the vegetative period for the location Zemun Polje, 2012 (4) was extremely unfavorable, 2017 (9) was unfavorable, 2009 (1), 2010 (2) and 2018 (10) were favorable, while the other years were average for maize cultivation (Table 2 and Table 3).

Table 2. Average monthly temperatures $\left({ }^{\circ} \mathrm{C}\right)$

Tabela 2. Srednje mesečne temperature $\left({ }^{\circ} \mathrm{C}\right)$

\begin{tabular}{lrrrrrrrc}
\hline \multirow{2}{*}{ Year } & \multicolumn{8}{c}{ Month } \\
\cline { 2 - 8 } & III & IV & V & VI & VII & VIII & IX & X \\
\hline $2009(1)$ & 8.5 & 16.2 & 19.8 & 21.1 & 24.0 & 24.5 & 21.0 & 14.0 \\
$2010(2)$ & 8.2 & 13.5 & 18.0 & 21.3 & 24.3 & 24.1 & 17.8 & 10.6 \\
$2011(3)$ & 8.0 & 14.6 & 17.3 & 22.4 & 24.2 & 24.8 & 21.6 & 12.1 \\
$2012(4)$ & 10.1 & 14.4 & 17.9 & 24.6 & 27.1 & 26.2 & 22.1 & 15.4 \\
$2013(5)$ & 6.6 & 14.9 & 19.7 & 21.9 & 23.8 & 23.7 & 16.9 & 15.3 \\
$2014(6)$ & 10.8 & 13.7 & 17.4 & 21.1 & 23.2 & 22.6 & 18.0 & 14.1 \\
$2015(7)$ & 8.1 & 12.9 & 19.1 & 22.1 & 26.4 & 25.7 & 20.2 & 12.4 \\
$2016(8)$ & 8.8 & 15.3 & 17.6 & 23.0 & 24.2 & 22.3 & 19.4 & 11.2 \\
$2017(9)$ & 11.0 & 12.4 & 18.6 & 24.4 & 25.5 & 25.8 & 18.4 & 13.3 \\
$2018(10)$ & 6.4 & 18.0 & 21.7 & 22.7 & 23.6 & 25.7 & 19.8 & 15.9 \\
\hline
\end{tabular}


Table 3. Monthly precipitation ( $\mathrm{mm}$ )

Tabela 3. Količina padavina po mesecima $(\mathrm{mm})$

\begin{tabular}{lrrrrrrrrr}
\hline \multirow{2}{*}{ Year } & \multicolumn{8}{c}{ Month } & \multicolumn{1}{c}{ V } \\
\cline { 2 - 7 } & III & \multicolumn{1}{c}{ IV } & \multicolumn{1}{c}{ V } & \multicolumn{1}{c}{ VI } & VII & VIII & \multicolumn{1}{c}{ IX } & \multicolumn{1}{c}{ X } & \\
\hline $2009(1)$ & 63.0 & 6.0 & 34.0 & 153.0 & 79.0 & 45.0 & 4.0 & 101.0 & 485.0 \\
$2010(2)$ & 38.4 & 50.7 & 64.1 & 167.3 & 35.6 & 68.2 & 68.0 & 42.7 & 535.0 \\
$2011(3)$ & 17.4 & 14.9 & 89.6 & 25.9 & 66.9 & 67.9 & 36.4 & 26.7 & 345.7 \\
$2012(4)$ & 10.7 & 56.2 & 58.5 & 14.8 & 19.8 & 4.8 & 20.7 & 41.3 & 226.8 \\
$2013(5)$ & 96.2 & 14.9 & 93.9 & 37.8 & 16.0 & 12.7 & 70.1 & 21.9 & 363.5 \\
$2014(6)$ & 46.9 & 84.8 & 192.5 & 71.2 & 187.4 & 41.0 & 75.6 & 56.6 & 756.0 \\
$2015(7)$ & 99.1 & 19.7 & 97.8 & 31.1 & 7.2 & 56.0 & 73.6 & 65.1 & 449.6 \\
$2016(8)$ & 71.1 & 51.9 & 47.4 & 107.4 & 33.6 & 43.2 & 36.6 & 60.3 & 451.5 \\
$2017(9)$ & 21.3 & 47.1 & 49.2 & 39.0 & 26.7 & 23.7 & 36.6 & 62.0 & 305.6 \\
$2018(10)$ & 32.4 & 24.6 & 39.0 & 150.1 & 61.9 & 44.0 & 16.9 & 20.8 & 389.7 \\
\hline
\end{tabular}

\section{Laboratory analyses}

Ten average maize ears per replicate were selected for further laboratory analyses. Ear properties, i.e. yield components: ear length (EL), ear weight (EW), number of kernel rows per ear (NKR), number of kernels per ear (NKE), cob weight (CW), and ear kernel weight (EKW), were determined by standard measuring procedures. Methods applied for determining kernel physical properties: 1000-kernel weight (TKW), test weight (TW), kernel density (KD), milling response (MR), percentage of hard endosperm portion (HE) in kernel weight, percentage of soft endosperm portion (SE) in kernel weight, and water absorption index (WAI), were described in detail in previously published paper (Radosavljević, et al., 2000). Kernel density (KD) or specific gravity was determined in a specially designed glass column based on the difference in levels of absorbed $96 \%$ ethanol before and after immersion of 100 kernels of previously determined mass. The water absorption index was obtained by measuring the amount of water that is absorbed by a certain amount of maize kernels under precisely defined conditions. The milling response (MR) determined by the Stenvert-Pomeranz test (Pomeranz et al., 1985) is a measure of kernel hardness which represents the time (s) necessary for $20 \mathrm{~g}$ of maize kernels to be ground in a micro hammer-mill at $3600 \mathrm{rpm}$ and pass through 2-mm sieve until the top level of the material collected in a glass cylinder $(125 \times 25 \mathrm{~mm})$ reaches the level of $17 \mathrm{ml}$. The samples of cornmeal obtained after grinding maize kernels during the test are merged and sieved through 0.5 $\mathrm{mm}$ diameter nylon mesh. The fraction that is sifted through the sieve is denoted as the soft endosperm, and the remaining one as hard endosperm. The fractions were measured afterwards, and the hard and soft endosperm portion was calculated.

To determine the kernel structure, i.e. the portion of pericarp (Per), germ (Germ) and endosperm (End) of the maize hybrids, $2 \times$ 100 kernels, previously soaked in water for 12 $h$, were dissected by hand. After drying, the weight of each kernel's fraction was measured and its portion in the whole kernel weight was calculated.

The whole grain maize flour was obtained by a process of dry grind milling (Perten Instruments, Hägersten, Sweden) for fine samples preparation (mesh $0.5 \mathrm{~mm}$ ). Kernel moisture was determined by drying the ground kernel samples at $105^{\circ} \mathrm{C}$ to a constant weight. The starch content was determined by Ewers polarimetric method (ISO 10520, 1997). The total protein content was determined by the Kjeldahl method as the total nitrogen multiplied by 6.25 (AOAC, 1990). The oil content was determined according to the Soxhlet standard method (AOAC, 2000). Crude fiber 
content was determined by Weende method adjusted for Fibretec ${ }^{\mathrm{TM}}$ Systems, Foss, Denmark (Agricultural food products, 1993). The ash content was determined by the slow combustion of the sample at $650^{\circ} \mathrm{C}$ (AOAC, 1990). The results are expressed in the percentages per dry matter (d.m.). All analyses were performed in two replicates.

\section{Statistical analysis}

Statistical package IBM SPSS Statistics 25 was used for data analysis. Data were individually processed by principal component analysis (PCA), for all groups of traits.

\section{Results and discussion}

The PCA was applied separately on the four examined groups of traits. To have a clearer insight into their interdependence, the aim was to form a smaller number of uncorrelated artificial variables (PCA axes) from a larger number of mutually correlated parameters. Table 4 showed the values of variance included in statistically significant PCA axes, i.e. PCA axes with Eigen values bigger than one. Table 5 shows which parameters define which specific axis, as well as the correlations.

Table 4. Total percentage of variance explained by the PCA

Tabela 4. Procenat varijanse obuhvaćen PC analizom

\begin{tabular}{lcccccccc}
\hline & Ear properties & \multicolumn{2}{c}{$\begin{array}{c}\text { Physical properties } \\
\text { of kernels }\end{array}$} & \multicolumn{2}{c}{ Kernel structure } & \multicolumn{2}{c}{$\begin{array}{c}\text { Chemical } \\
\text { composition of } \\
\text { kernels }\end{array}$} \\
\cline { 2 - 9 } & EiV & V & EiV & V & EiV & V & EiV & V \\
\hline PCA1 & $3.91^{*}$ & 65.217 & 2.74 & 39.170 & 2.17 & 72.264 & 1.76 & 35.148 \\
PCA2 & $1.24^{*}$ & 20.725 & 1.45 & 20.762 & 1.02 & 27.295 & 1.17 & 23.366 \\
PCA3 & & & 1.06 & 15.205 & & & 1.06 & 21.179 \\
Cumulative & & 85.941 & & 75.137 & & 99.559 & & 79.690 \\
\hline
\end{tabular}

EiV - Eigen value, ${ }^{*}$ - Eigen value $>1$ considered as significant, V - \% of Variance, BCCG - basic chemical composition of the grain

Six examined parameters of the maize ear (i.e. yield components) formed two significant PCA axes that include $85.941 \%$ of the variance (PCA1 and PCA2, with 65.217 and $20.725 \%$ of the variance for each axis, respectively) (Table 4). The first axis was defined by the ear length, the ear weight, the number of kernels per ear, the cob weight and the ear kernel weight, where the observed characteristics were mutually in positive correlations. The second axis was defined by the number of kernel rows, and this parameter was not correlated with other parameters of the maize ear (Table 5).
These correlations are noticed in the PC analysis for ear parameters (Figure 1). The analyzed hybrids were labeled with corresponding markers (legend), while on the chart they were labeled with an ordinal number $(1-6)$ and the number of the year in which they were tested $(1-10)$. The same marker colour indicated the same father (red - ZPL M1; black - ZPL M2; green - ZPL M3), while the same marker shape indicated the same mother in the analyzed hybrid ( $\mathrm{x}$ - ZPL F1; • - ZPL F2; - - ZPL F3) (Table 1). It was found that, in a different year of testing, the number of kernel rows varied the least for the same hybrid. In a study on 
maize yield enhancement, Bomert et al. (2013) by genotypic effect and by variation in size of reported that the number of kernel rows is a inflorescence meristem with the potential to stable trait and that it is predominantly defined increase yield.

Table 5. Component matrix of PCAs

Tabela 5. Komponente PCA matrice

\begin{tabular}{lccc}
\hline \multirow{2}{*}{ Original Variables } & \multicolumn{3}{c}{ PCA axes } \\
\cline { 2 - 4 } Ear properties & PCA1 & PCA2 & PCA3 \\
\hline EL & & & \\
EW & 0.868 & -0.240 & \\
NKR & 0.959 & -0.134 & \\
NKE & 0.280 & 0.928 & \\
CW & 0.776 & 0.490 & \\
EKW & 0.816 & -0.226 & \\
\hline
\end{tabular}

Physical properties of kernels

\begin{tabular}{lrrr}
\hline TKW & -0.034 & 0.820 & -0.298 \\
TW & 0.665 & 0.462 & 0.369 \\
KD & 0.429 & 0.627 & 0.319 \\
MR & 0.050 & 0.737 & 0.013 \\
HE & 0.849 & 0.011 & -0.197 \\
SE & -0.891 & -0.040 & 0.260 \\
WAI & -0.285 & -0.105 & 0.875 \\
\hline Kernel structure & & & \\
\hline Per & & 0.987 & \\
Germ & 0.157 & 0.038 & \\
End & 0.997 & -0.468 & -0.398 \\
\hline Chemical composition of kernels & -0.879 & & 0.103 \\
\hline Star & & -0.781 & -0.352 \\
Prot & 0.075 & 0.124 & 0.898 \\
Oil & 0.883 & 0.757 & -0.030 \\
C & 0.203 & 0.011 & \\
Ash & 0.082 & -0.015 & \\
\hline
\end{tabular}

EL - Ear length (cm); EW - Ear weight (g); NKR — Number of kernel rows; NKE - Number of kernels per ear; CW - Cob weight (g); EKW - Ear kernel weight (g); TKW - 1000 kernel weight (g); TW - test

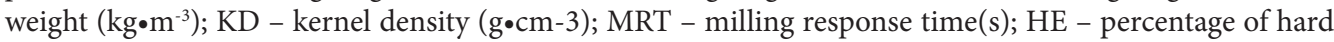
endosperm portion in kernel weight, SE - percentage of soft endosperm portion in kernel weight; WAI water absorption index; Per - percentage of pericarp portion in kernel weight; Germ - percentage of germ portion in kernel weight; End - percentage of endosperm; Star - Starch (\%); Prot - total protein (\%); C crude fiber (\%); Ash - Ash (\%). 


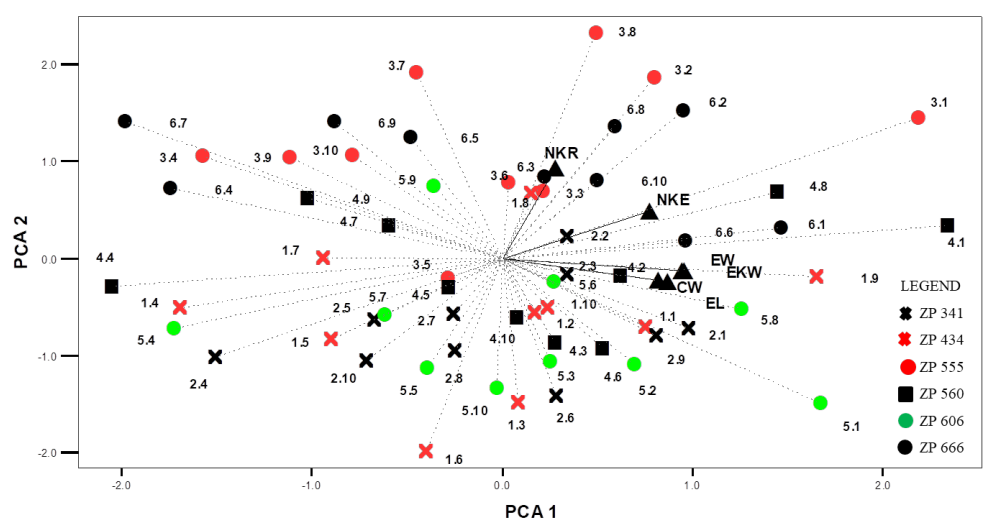

Figure 1. PCA for the ear parameters

Grafikon 1. PC analiza svojstava klipa
In the extremely dry experimental 2012 (4), all the tested hybrids showed approximately the same but lower values of all other yield components (negative values of the PCA1 axis), only differing in the number of kernel rows. In experimental 2009 (1), being optimal for maize, hybrids $(3,4,5)$ of later maturity groups showed the highest values of yield components that defined the PCA1 axis. This indicated their higher yield potential, which was expressed under favorable conditions (Çakir, 2004).

Seven examined kernel physical parameters formed three PCA axes covering $75.137 \%$ of the variance (Table 4). The first axis was defined with test weight (TW) as well as the portion of hard endosperm (HE) and soft endosperm (SE) which are mutually under negative correlation. The PCA2 axis was defined by 1000-kernel weight (TKW), kernel density (KD), and milling response (MR), being in mutual positive correlation. The third axis (PCA3) was defined by the water absorption index (WAI) (Tab 5). Similar conclusions were drawn by Uriarte-Aceves et al. (2019), who found that kernel density (KD) and test weight (TW) in white dent maize were positively correlated, while KD and TKW were in a non-significant negative correlation.
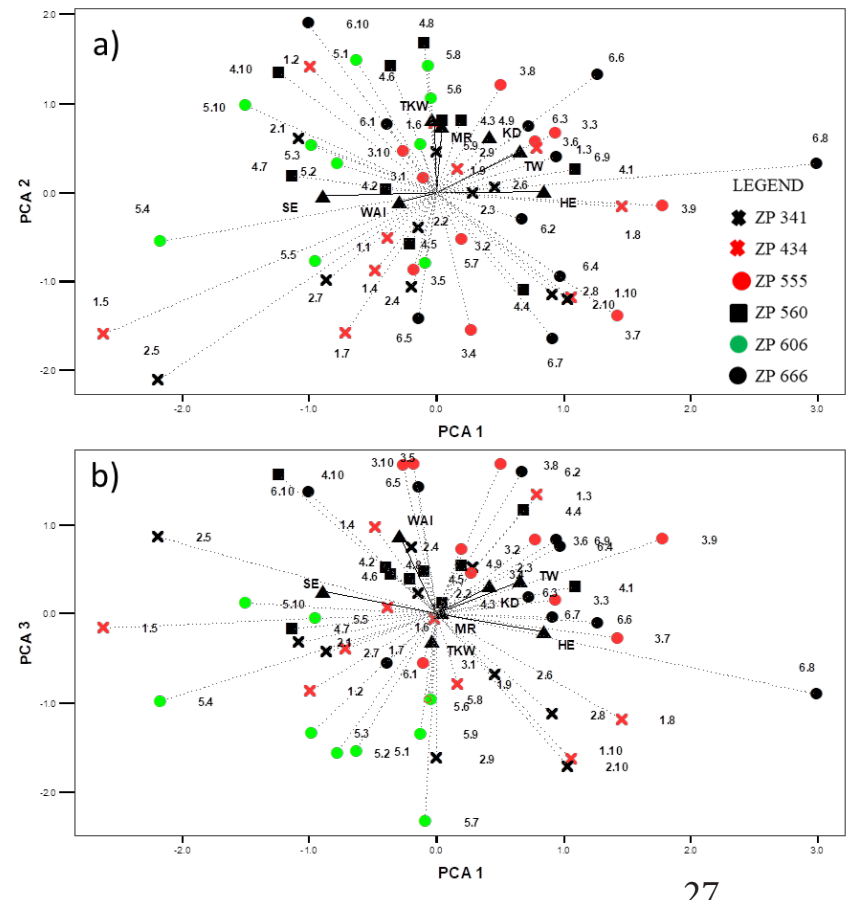

Figure 2. PCA for the physical parameters of kernels: a) PCA1PCA2 b) PCA1-PCA3

Grafikon 2. PC analiza fizičkih svojstava zrna: a) PCA1-PCA2 b) $P C A 1-P C A 3$ 
Figures $2 \mathrm{a}$ and $2 \mathrm{~b}$ showed that the genetic constitution of hybrids had a great influence on the portion of soft and hard endosperm, in addition to the influence of the environment (i.e., year of cultivation). Thus, the hybrid whose paternal component is ZPL M3, had a higher portion of soft endosperm than other hybrids, regardless of the year of cultivation (negative values of PCA1 axis). It was concluded that the changes in other parameters were more influenced by the environmental factors (Figure 2a). Parameters such as kernel hardness and vitreousness (hard to soft endosperm ratio) were strongly determined by genotype and significantly correlated with technological quality and final utilization of maize (Radosavljević et al., 2000; Milašinović-Šeremešić et al., 2019). The ratio of hard (vitreous) to soft (floury) endosperm is an important physical trait that influences hardness, post-harvest resistance to pests, rate of starch digestibility, and semolina yield for food production (Gayral et al., 2015). Kernels with a low test weight tend to have a low percentage of hard endosperm (Correa et al., 2002). Nutritional value, as well as technological traits (millability, fermentability, etc.) may differ from genotype to genotype due to variations in kernel hardness and its chemical composition (Milašinović et al., 2007; Semenčenko et al., 2013). A higher share of soft endosperm fraction facilitates starch isolation in the wet-milling process, as well as a degradation of the starch granules during enzymatic hydrolysis, which are preferable for a higher starch yield, recovery and purity, as well as bioethanol yield (Milašinović et al., 2007; Semenčenko et al., 2015, 2013).

Hybrids ZP 555, ZP 560 and ZP 666 showed higher values of water absorption index (WAI), as seen in Figure 2b.

The proportion of germ and endosperm, mutually in negative correlation, defined the first axis of PC analysis for the Kernel structure. The second axis was defined by the portion of the pericarp (Table 5). Both axes covered $99.559 \%$ of the variability (Table 4 ).

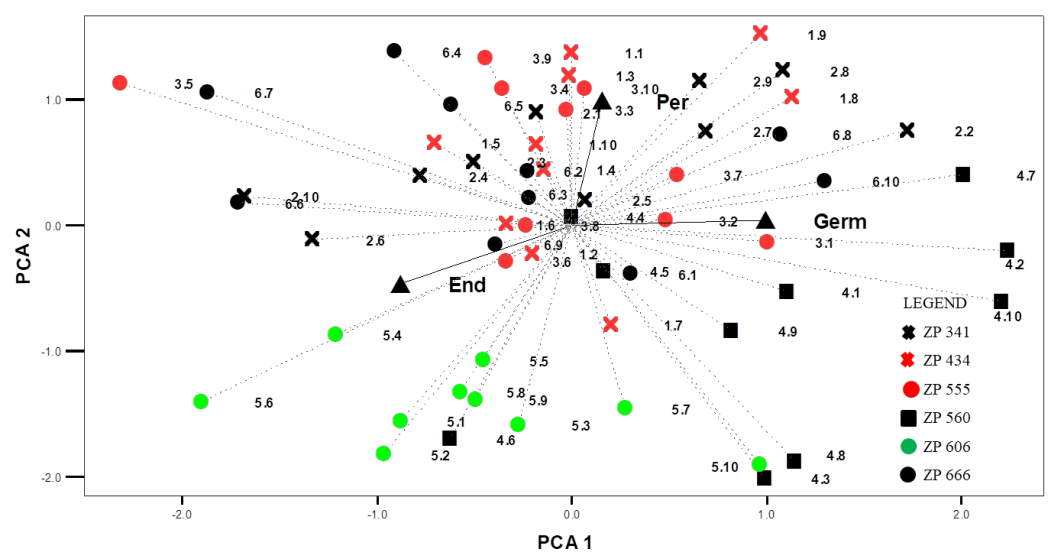

Figure 3. PC analysis for the kernel structure

Grafikon 3. PC analiza strukture zrna

Regardless of the growth conditions, hybrids ZP 606 and ZP 560 had a lower portion of pericarp in the kernel, compared to other tested hybrids (Figure 3). Also, by evaluating the two very similar hybrids, ZP 341 and ZP 434 , it can be noticed that in a ten-year period, the hybrid ZP 341 had a similar, uniform, endosperm-germ ratio, while the pericarp content varied more. In hybrid ZP 434, how- ever, variation in the endosperm-germ ratio was much more pronounced, depending on the year of cultivation. Hybrids that shared the same maternal component (i.e., ZP 555, ZP 666 and ZP 606) differed in the portion of pericarp in the kernel while the portion of endosperm and germ varied equally, depending on the year of cultivation. Troyer and Rocheford (2002) stated that even a very small differ- 
ence in the genetic constitution of a hybrid can make a significant difference in the manifestation of traits during cultivation in the field.

Six parameters that determine the basic grain chemical composition of the investigated hybrids formed three significant PCA axes. The first PCA axis was defined by the total protein and ash content, mutually in positive correlation. The second axis was defined by the content of starch and oil, being in negative correlation. The third axis was defined by the crude fiber content. All three axes cumulatively captured $79.690 \%$ of the variability (Tables 4 and 5).

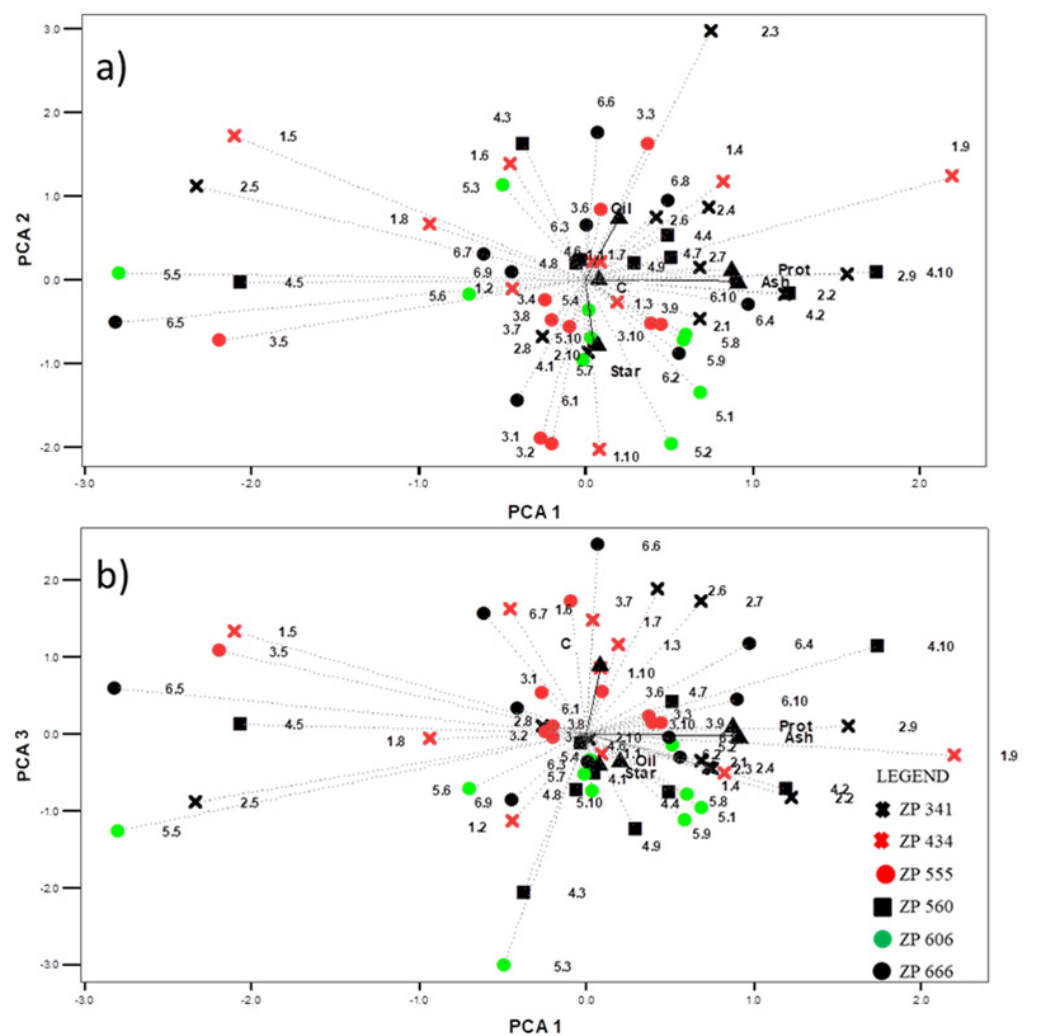

Figure 4. PC analysis for the chemical composition of the kernel: a) PCA1PCA2 b) $P C A 1-P C A 3$

Slika 4. PC analiza hemijskog sastava zrna: a) $P C A 1-P C A 2$ b) $P C A 1-P C A 3$
Depending on the genetic background and environmental conditions during the production, maize grain, on average, contains 54 $-74 \%$ starch, $8-14 \%$ protein, $3-6 \%$ oil, and $1.5-3 \%$ crude fiber (Eckoff et al., 2009, Nikolić et al., 2020). PC analysis for the basic chemical composition of the kernel showed that the examined hybrids which were grown in 2013 (5) stood out for their extremely low total protein content (extremely negative values of the PCA1 score) (Figure 4a). In maize grown under stress conditions, Oury and Godin (2007) reported a negative correlation between total protein content and kernel weight, whereas Uriarte-Aceves et al. (2019) reported a significant positive correlation between protein content and test weight.

Concerning the average precipitation and monthly temperatures (Tables 2 and 3), it can be concluded that 2013 had a wet and cold spring, a relatively cold summer with a small amount of precipitation, especially in July and August, and a wet and extremely cold September. High-temperature stress reduced protein synthesis in maize and changed the chemical structure of proteins (Monjardino et al., 2005). Unfavorable distribution of precipitation and low temperatures adversely affected the protein 
accumulation in the grain of all hybrids. Nejad et al. (2017) reported that the total protein content in the grain depends on the content of available nitrogen and soil moisture during the grain filling period. In mentioned 2013, medium-early hybrids ZP 341 and ZP 434 accumulated higher oil content, while medium-late maturing hybrids accumulated higher starch content in the kernel. Regarding all hybrids and the experimental years, the highest starch content was obtained mostly in 2009 (1) and 2018 (10), being optimal for maize production in terms of distribution and amount of precipitation. In the extremely dry 2012 (4) and the dry 2017 (9), hybrids 1, 2, 4, 6 tended to increase the total protein and ash content.

The main chemical component of maize kernel is starch - a carbohydrate that constitutes, on average, approximately $70 \%$ of this cereal grain (Milašinović et al., 2007). Mousavi et al. (2013) had found that heat stress at flowering considerably decreased the starch content due to the reduction in photosynthetic activities, leading to an increase in the kernel total protein content. The correlation analysis performed by Uriarte-Aceves et al. (2019) showed that the starch content correlated negatively with the kernel density at a highly significant level, implying the influence of starch contents on endosperm texture. On the other hand, Correa et al. (2002) concluded that the kernel density is associated with kernel hardness, which means that firmer kernels presumably contain less starch.

In dry experimental years, medium-early maturity hybrids ZP 341 and ZP 434 also had increased kernel oil content while increased oil content in other hybrids was mostly observed in years that were moderately favorable for maize such as 2011 was.

Based on the results displayed in Figure 4b, it can be noticed that the crude fiber content that defines the PCA3 axis, varied far less when a single hybrid was observed over the years, than the total protein content that defines the PCA1 axis. Namely, the hybrid ZP 606, as well as, the hybrid ZP 560 had a lower crude fiber content compared to other hybrids. These very hybrids also had a lower portion of pericarp in the kernel structure.

\section{Conclusion}

According to the results obtained after a decade of testing the yield components and the parameters of technological quality of six commercial ZP maize hybrids, it can be concluded that the analyzed parameters, in addition to the genetic factor, were greatly influenced by the environmental conditions.

In addition to the genotype, the amount and the distribution of precipitation during the vegetative period influenced the yield components (i.e. physical characteristics of the maize ear) the most. The number of kernel rows varied the least in different years. The portion of soft and hard endosperm, although its variation depended on environmental conditions, was unequivocally defined by the genetic constitution of the hybrid. The same conclusion can be drawn for the portion of the pericarp, where a different paternal component separated the hybrid ZP 606 from the hybrids ZP 555 and ZP 666, respectively, with which it shared the same maternal component. The portion of endosperm and germ was significantly more influenced by environmental factors. The variations in the basic chemical composition of the grain of the examined maize hybrids were far more influenced by environmental factors than by the genotype. In long-term trials, the greatest variability was shown for the total protein content in the grain. Low temperatures and lack of moisture during the grain filling period in 2013 resulted in the very low protein content in the grain of all tested hybrids. In years with a favorable distribution and amount of precipitation, all analyzed hybrids tended to increase the accumulation of starch in the grain. Moderately favorable years stimulated the accumulation of oil in the grain. In addition, the observed parameters were greatly influenced by environmental factors, so it is difficult to single out a hybrid that can be recommended for a specific purpose.

As grain yield is still the most important agronomic trait, there are maize hybrids with high yield potential present on the market, but also of the very similar genetic constitution and thus, of similar technological properties 
and nutritional quality. The development of novel breeding programs that would include more targeted approaches directed towards creating maize hybrids intended for specific purposes is of paramount importance. Special attention should be paid to enabling the development of hybrids with increased nutritional and technological quality of both the starting material as well as the parental lines.

\section{Acknowledgments}

This research was supported by the Ministry of Education, Science and Technological Development, Republic of Serbia, under Grant no. 451-03-68/2020-14/200040.

\section{References}

Agricultural food products (1993): Determination of crude fibre. General method NFV03-040 (status: certified standard ref. ISO 5498), Assn. Fr. De Normalisation, Paris.

Andorf C, Beavis WD, Hufford M, Smith S, Suza WP, Wang K, Woodhouse M, Yu J, Lübberstedt T (2019): Technological advances in maize breeding: past, present and future. Theoretical and Applied Genetics, 132: 817-849.

AOAC (1990): Association of Official Analytical Chemists, Official Methods of Analysis, ed. by Herlich K. AOAC, Arlington, VA. pp. 70-84.

AOAC (2000): Association of Official Analytical Chemists, Official Methods of Analysis, 17th international edition. AOAC International, Gaithersburg, MD.

Babić M, Andjelković V, Drinic S, Konstantinov K (2011): The conventional and contemporary technologies in maize (Zea mays L.) breeding at Maize Research Institute Zemun Polje. Maydica, 56 (2): 155164.

Babić V, Andjelković V, Babić M, Pavlov M, Kaitović Ž, Filipović M (2012): Role of genetic resources in diversity increasment of commercial maize hybrids. Third International Scientific Symposium - AGROSYM 2012, Jahorina, 15-17 November. Book of Abstracts, 2012, On CD, 97-103.
Babić V, Pavlov M, Boćanski J (2016): Stanje i perspektive u oplemenjivačkom i semenarskom sektoru Srbije. Selekcija i semenarstvo, 22 (2): 19-27.

Barutcular C, El Sabagh A, Koc M, Ratnasekera D. (2017) Relationships between grain yield and physiological traits of durum wheat varieties under drought and high temperature stress in Mediterranean environments. Fresenius Environmental Bulletin, 26:4282-4291.

Bommert P, Nagasawa NS, Jackson D (2013): Quantitative variation in maize kernel row number is controlled by the FASCIATED EAR2 locus Nature Genetics 45 (3): 334338.

Çakir R (2004): Effect of water stress at different development stages on vegetative and reproductive growth of corn, Field Crops Research, 89 (1): 1-16.

Correa CES, Shaver RD, Pereira MN, Lauer JG, Kohn K (2002): Relationship between corn vitreousness and ruminal in situ starch degradability. Journal of Dairy Science, 85: 3008-3012.

Eckhoff SR, Watson SA (2009): Chapter 9: Corn and sorghum starches: Production, In J.N. BeMiller, R. L. Whistler (ed), Starch: Chemistry and Technology, third edition. Elsevier Inc. 373-439.

El Sabagh A, Barutcular C, Islam MS (2017): Relationships between stomatal conductance and yield under deficit irrigation in maize (Zea mays L.). Journal of Experimental Biology and Agricultural Sciences, 5:15-21.

Gayral M, Bakan B, Dalgalarrondo M, Elmorjani K, Delluc C, Brunet S, Linossier L, Morel M-H, Marion D (2015): Lipid partitioning in maize (Zea mays L.) endosperm highlights relationships among starch lipids, amylose, and vitreousness. Journal of Agricultural and Food Chemistry, 63: 3551-3558.

ISO 10520 (1997): Determination of starch content - Ewers polarimetric method. International standard, 1: 1-8.

Lu D, Cai X, Yan F, Sun X, Wang X, Lu W. (2014): Effects of high temperature after 
pollination on physicochemical properties of waxy maize flour during grain development. Journal of the Science of Food and Agriculture, 94:1416-1421.

Milašinović-Šeremešić $M$, Radosavljević $M$, Đuragić O, Srdić J (2021): Starch composition related to physical traits in maize kernel, Journal on Processing and Energy in Agriculture, 25 (2): 78-81.

Milašinović M, Radosavljević M, Dokić Lj, Jakovljević J (2007). Wet milling properties of ZP maize hybrids. Maydica, 52: 289-292.

Milašinović-Šeremešić M, Radosavljević M, Srdić J, Tomičić Z, Đuragić O (2019): Physical traits and nutritional quality of selected Serbian maize genotypes differing in kernel hardness and colour. Food and Feed Research, 46(1): 51-59.

Monjardino P, Smith AG, Jones RJ (2005): Heat stress effects on protein accumulation of maize endosperm. Crop Science, 45: 12031210.

Mousavi H, Lack S, Alavi FM. (2013): Analysis of correlation and stepwise regression between grain protein yield and related traits of maize in conditions of drought stress and zinc sulfate spraying. International Journal of Agriculture and Crop Sciences, 5: 2783-2788.

Nejad SMH, Alizadeh O, Amiri B, Barzegari M, Bayat ME. (2017): The effects of drought and heat stress on some physiological and agronomic characteristics of new hybrids of corn in the north of Khuzestan Province (Iran). EurAsian Journal of BioSciences, 11: 32-36

Nikolić V, Božinović S, Vančetović J, Radosavljević M, Žilić S (2020): Grain properties of yellow and red kernel hybrids from Serbia. Selekcija i semenarstvo, 26 (2): 7-14.

Oury F, Godin C. (2007): Yield and grain protein concentration in bread wheat: How to use the negative relationship between the two characters to identify favorable genotypes? Euphytica, 157: 45-57.

Pomeranz Y, Czuchjowska Z, Martin C R, Lai F (1985): Determination of corn hardness by Stenvert hardness tester, Cereal Chemistry, 62: 108-110.
Radosavljević M, Bekrić V, Božović I, Jakovljević J (2000): Physical and chemical properties of various corn genotypes as a criterion of technological quality. Genetika, 32 (3): 319-329.

Semenčenko V, Radosavljević $M$, Terzić D, Milašinović-Šeremešić, Mojović Lj, Mladenović Drinić S (2015): Influence of maize hybrid on bioethanol yield and quality of dried distillers' grains. Selekcija i semenarstvo, 21(2): 11-22.

Semenčenko V, Mojović L, Đukić-Vuković A, Radosavljević M, Terzić D, Milašinović-Šeremešić M (2013): Suitability of some selected maize hybrids from Serbia for the production of bioethanol and dried distillers' grains with solubles. Journal of the Science of Food and Agriculture, 93, 811-818.

Troyer AF, Rocheford TR (2002): Germplasm ownership: Related corn inbreds, Crop Science 42: 3-11.

Uriarte-Aceves PM, Sopade PA, Rangel-Peraza JG (2019): Physical, chemical and wetmilling properties of commercial white maize hybrids cultivated in México. Journal of Food Processing and Preservation, 43:e13998.

Vančetović J, Žilić S, Božinović S (2012): ZP maize hybrids with red kernel. Selekcija i semenarstvo, 18: 1-8.

World Agricultural Production.com (2021): World Corn Production 2020/2021, January 2021.

Žilić S, Serpen A, Akillioglu G, Gokmen V, Vančetović J (2012): Phenolic compounds, carotenoids, anthocyanins, and antioxidant capacity of colored maize (Zea mays L.) kernels. Journal of Agricultural and Food Chemistry, 60: 1224-1231. 


\title{
VARIJABILNOST I MEĐUZAVISNOST OSNOVNIH PARAMETARA TEHNOLOŠKOG KVALITETA HIBRIDA KUKURUZA U DUGOROČNIM ISTRAŽIVANJIMA
}

\author{
Valentina Nikolić, Vojka Babić, Natalija Kravić, Milomir Filipović, \\ Slađana Žilić, Marijana Simić, Milica Radosavljević
}

\begin{abstract}
Sažetak
U procesu hibridnog oplemenjivanja kukuruza, najviše pažnje se posvećuje povećanju nivoa i stabilnosti prinosa, dok je kvalitet zrna od sekundarnog značaja. Sami principi hibridnog oplemenjivanja, kao i ekonomski aspekti i konkurencija između različitih oplemenjivačkih kuća, doveli su do enormnog suženja genetičke osnove komercijalnih hibrida kukuruza. Na tržištu je istovremeno najčešće prisutan mali broj, često srodnih hibrida sličnog tehnološkog i nutritivnog kvaliteta. Za ovo istraživanje je odabrano šest ZP hibrida kukuruza najprodavanijih u prethodnih deset godina. U periodu od 2009-2018. godine, praćene su, kako komponente prinosa, tako i parametri tehnološkog i nutritivnog kvaliteta zrna. Utvrđeno je da su ispitivani parametri veoma varirali u različitim godinama gajenja, kao i da su neki parametri bili pod većim uticajem genotipa (broj redova zrna, udeo perikarpa i sirove celuloze), a neki pod većim uticajem spoljašnje sredine (masa zrna po klipu, udeo ukupnih proteina, skroba i ulja, respektivno). Količina i raspored padavina u toku vegetativnog perioda su uticali ne samo na komponente prinosa, odnosno na prinos zrna, već i na parametre tehnološkog kvaliteta i nutritivna svojstva. Na osnovu posmatranih roditeljskih komponenata, evidentno je da se radi o srodnim hibridima koji, bez obzira na visoke interakcije između genotipa i spoljašnje sredine, posledično imaju slične parametre tehnološkog kvaliteta kao i nutritivni sastav. Neophodno je razvijati posebne oplemenjivačke programe koji imaju za cilj stvaranje kako početnog materijala, tako i roditeljskih komponenata, kako bi se na tržištu obezbedili hibridi poboljšanog tehnološkog kvaliteta i nutritivnih svojstava i na taj način zadovoljile potrebe prerađivačke industrije za sirovinama određenih karakteristika.
\end{abstract}

Ključne reči: komercijalni hibridi kukuruza, komponete prinosa, fizičke karakteristike zrna, osnovni hemijski sastav zrna, PCA analiza.

Primljen: 1.09.2021.

Prihvaćen: 7.10.2021. 